\title{
Tuberkulosis Milier dan HIV-AIDS dengan Drug-induced Hepatitis
}

Hans Wincen $W^{1}$, Zulkarnain $\mathrm{A}^{2}$, Fauzar ${ }^{2}$

\begin{abstract}
Abstrak
TB milier merupakan komplikasi dari suatu fokus infeksi tuberkulosis yang disebarkan secara hematogen. Gambaran berupa bercak-bercak halus yang umumnya tersebar merata pada seluruh lapangan paru. Pemberian terapi OAT pada pasien TB dengan HIV perlu mendapat perhatian khusus karena selain OAT sendiri dapat menimbulkan drug-induced hepatitis, pemberian OAT dengan ARV harus dilakukan secara benar agar tidak timbul efek samping obat pada pasien. Telah dilaporkan suatu kasus seorang laki-laki umur 26 tahun dengan TB Milier-HIV dengan drug-induced hepatitis dirawat di RSUP M Djamil Padang. Pasien dikonsulkan ke Pulmonologi dengan keluhan mata kuning dan urin seperti teh pekat setelah pemberian obat anti tuberkulosis selama 18 hari dan anti retroviral selama 4 hari. Pada pemeriksaan fisik ditemukan sklera yang ikterik, kandidiasis oral, hepatomegali. Dari pemeriksaan laboratorium didapatkan nilai SGPT $137 \mathrm{u} / \mathrm{L}$ dan SGOT $84 \mathrm{u} / \mathrm{L}$, bilirubin urin (+), Ig M anti HAV negatif, HBsAg non reaktif, Anti HCV 0,09 $(<1)$, rontgen thorak ditemukan kesan TB milier, USG Abdomen kesan hepatitis. Pada pasien dilakukan penghentian OAT kategori 1, kemudian diberikan terapi hepatoprotektor, streptomisin dan etambutol dengan desensitisasi pemberian INH dan rifampisin. Pasien kemudian mengalami perbaikan secara klinis dan laboratoris setelah terapi desensitisasi.
\end{abstract}

Kata kunci: drug-induced hepatitis, tuberkulosis, OAT, HIV

\section{Abstract}

Miliary tuberculosis (TB) is the widespread dissemination of Mycobacterium tuberculosis via hematogenous spread. Classic miliary TB is defined as milletlike seeding of TB bacilli in the lung, as evidenced on chest radiography. Giving anti tuberculosis drug for patient with TB-HIV needs special attention because it may cause drug-induced hepatitis. Besides, anti tuberculosis drug and anti retroviral therapy should be given in perfect way and perfect time to prevent the negative side effects on the patient. Reported a case, a 26 years old male patient with Milliary Tuberculosis and HIV-AIDS with Drug-induced Hepatitis at M Djamil Hospital Padang. Patient was admitted to Pulmonology consultant with chief complaint jaundice and dark-colored urine. The level of SGPT and SGOT were 137 u/L and 84 u/L respectively, urin bilirubin (+), Ig M anti HAV negative, HBsAg non reactive, Anti HCV 0,09 (<1), Chest radiography revealed smooth spots which spread in the whole lung, the result of abdominal USG was hepatitis. Then we decided to stop giving this patient category 1 of fixed dose combination of anti tuberculosis drug and start to give him hepatoprotector therapy, streptomycin, and ethambutol while we desensitize him to isoniazid and rifampicin. There was a good improvement clinically and in laboratory test results after the desensitization treatment.

Keywords:drug-induced hepatitis, tuberculosis, OAT, HIV

Affiliasi penulis : 1. Program Studi Pendidikan Profesi Dokter Spesialis-1 IImu Penyakit Dalam FK Unand/RSUP M Djamil Padang 2. Subbagian Pulmonologi Bagian IImu Penyakit Dalam FK Unand/RSUP M Djamil Padang

Korespondensi :pibipd@yahoo.comTelp: 0751-37771

\section{PENDAHULUAN}

Tuberkulosis milier adalah bentuk tuberkulosis yang ditandai dengan penyebaran luas ke dalam tubuh manusia dengan lesi ukuran kecil (1-5 $\mathrm{mm}$ ), namanya berasal dari pola yang khas terlihat pada rontgen dada dari banyak bintik-bintik kecil yang didistribusikan ke seluruh bidang paru-paru dengan tampilan yang mirip dengan milet biji, sehingga disebut TB 'miliaria'. Tuberkulosis milier adalah jenis tuberkulosis yang bervariasi dari infeksi progresif lambat hingga penyakit fulminan akut, ini disebabkan oleh penyebaran hematogen atau limfogen dari perkijuan yang terinfeksi ke dalam aliran darah dan mengenai banyak organ. ${ }^{1}$
Drug-induced hepatitis adalah kerusakan hat yang berkaitan dengan gangguan fungsi hati yang disebabkan oleh terpajan obat. The Food and Drug Administration (FDA) dan The Center for Biologics Evaluation and Research (CBER) mendefinisikan drug-induced hepatitis sebagai kerusakan hati yang ditandai dengan peningkatan level alanin aminotransferase (ALT/SGPT) lebih dari tiga kali batas atas nilai normal dan peningkatan level alkali fosfatase (ALP) lebih dari dua kali dari batas atas nilai normal atau peningkatan level bilirubin total lebih dari dua kali dari batas atas nilai normal jika berkaitan dengan peningkatan alanin aminotransferase atau alkali fosfatase. ${ }^{2}$

Penatalaksanaan drug-induced hepatitis dengan cara menghentikan obat penyebab terjadinya kerusakan hati, diikuti monitoring kondisi klinis dan indikator kerusakan hati secara laboratorium. Beberapa penulis menyarankan menghentikan obatobatan hepatotoksik jika ALT meningkat tiga kali atau lebih dibandingkan dengan normal. Lakukan segera 
upaya eliminasi obat atau metabolit secepatnya misalnya melalui dialisis atau plasmafaresis atau diberikan antidotnya. ${ }^{3,4}$

\section{LAPORAN KASUS}

Seorang pasien laki-laki usia 26 tahun dirawat di bangsal Penyakit Dalam RSUP M Djamil Padang dengan keluhan utama mata kuning yang semakin meningkat sejak 3 hari yang lalu. Pasien sudah dikenal menderita TB Milier dengan HIV sejak 1 bulan yang lalu dan mendapatkan terapi yaitu obat anti tuberkulosis kombinasi dosis tetap selama 18 hari, dan anti retroviral selama 4 hari. Pasien tidak pernah menderita sakit kuning sebelumnya. Pasien belum menikah, memiliki riwayat seks bebas dengan PSK sejak tahun 2011. Pasien tidak pernah memakai jarum suntik bersama, tidak terdapat tatto, tidak pernah mendapat transfusi darah.

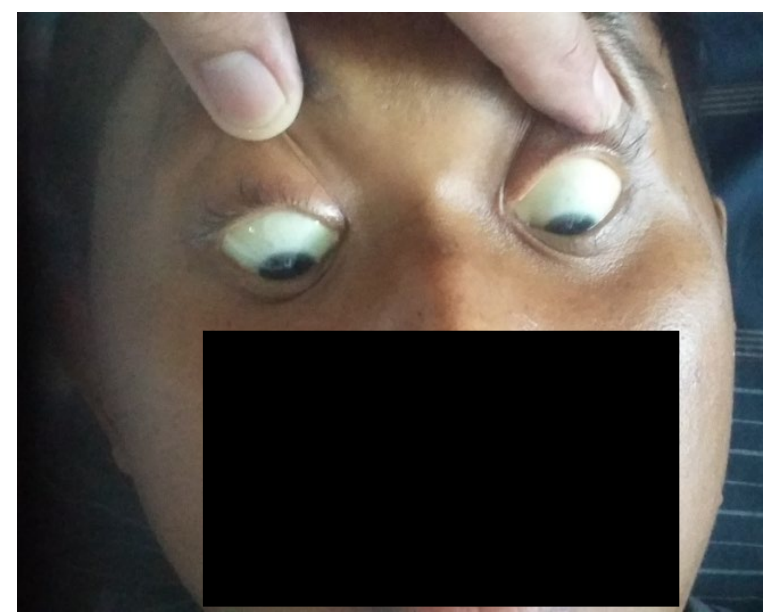

Gambar 1. Foto pasien sebelum menjalani terapi.

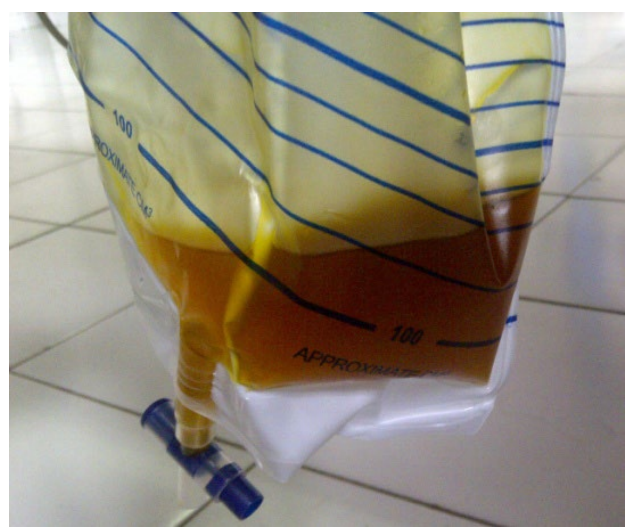

Gambar 2. Urin pasien dengan bilirubin (+).

Pada pemeriksaan fisik ditemukan sklera yang ikterik, kandidiasis oral, hepatomegali. Dari pemeriksaan laboratorium didapatkan nilai SGPT 137 $\mathrm{u} / \mathrm{L}$ dan SGOT $84 \mathrm{u} / \mathrm{L}$, bilirubin urin (+), bilirubin indirek $2,1 \mathrm{mg} / \mathrm{dl}$, bilirubin direk $8,3 \mathrm{mg} / \mathrm{dl}$, alkali fosfatase 142 u/l (40-130), gamma GT 459 u/l (0-38), Ig M anti HAV negatif, HBsAg non reaktif, Anti HCV 0,09 (<1). Pada pemeriksaan penunjang yaitu rontgen thorak ditemukan kesan TB milier. Pada pemeriksaan USG abdomen ditemukan gambaran hepatitis. Pasien kemudian dikonsulkan ke subbagian Pulmonologi.

Pada pasien dilakukan penghentian OAT kategori 1, kemudian diberikan terapi streptomisin dan etambutol dengan desensitisasi pemberian hepatoprotektor, INH dan rifampisin. Pasien kemudian mengalami perbaikan secara klinis dan laboratoris setelah terapi desensitisasi.

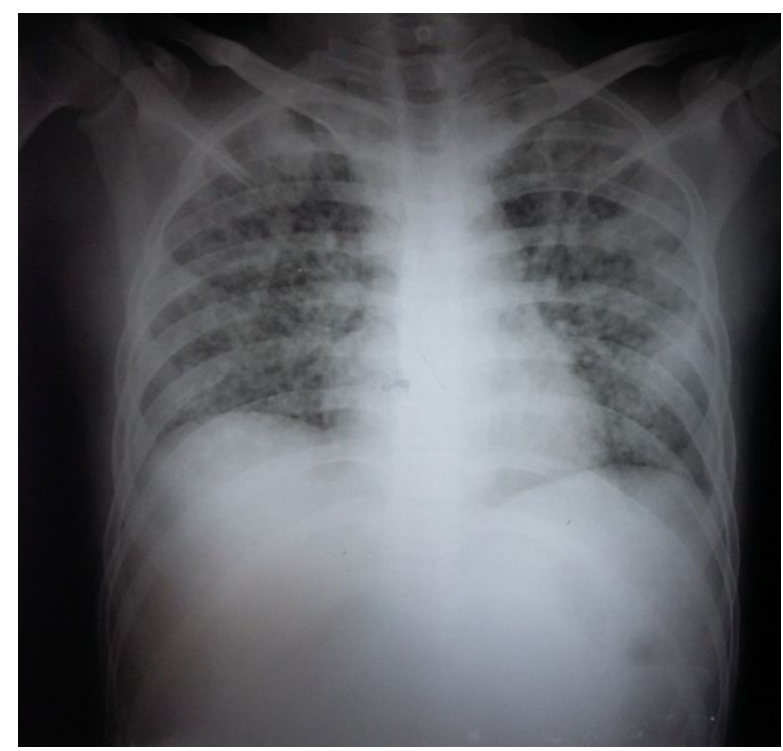

Gambar 3. Hasil Rontgen Thorak

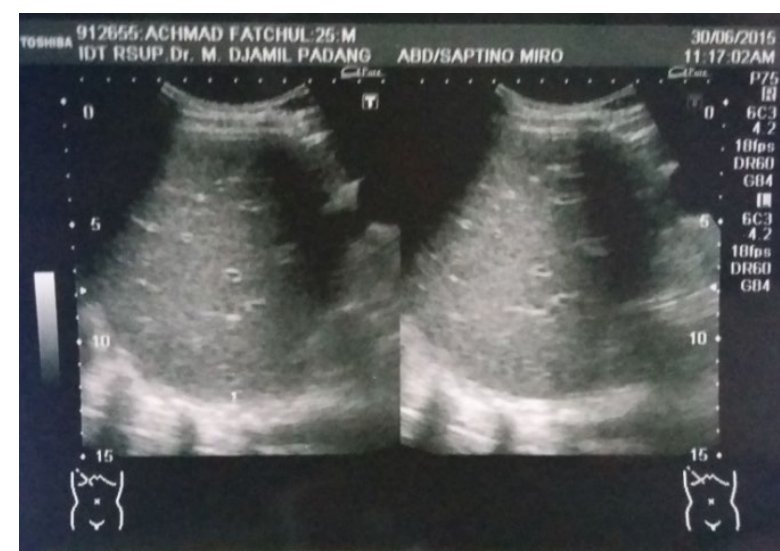

Gambar 4. USG Abdomen

\section{PEMBAHASAN}

Telah dirawat seorang laki-laki usia 40 tahun di bangsal penyakit dalam RSUP M Djamil Padang dengan diagnosis Tuberkulosis Milier dan HIV-AIDS dengan drug-induced hepatitis.

Diagnosis pada pasien ini ditegakkan bersadarkan anamnesis, pemeriksaan fisik dan pemeriksaan penunjang. Pada anamnesis didapatkan keluhan pasien berupa mual dan muntah yang meningkat sejak 1 minggu sebelum masuk rumah sakit, pasien sebelumnya dirawat di bangsal penyakit dalam RSUP M. Djamil Padang dengan diagnosis HIV-AIDS dengan TB milier dan mendapatkan obat paket paru yang diminum satu kali 3 tablet sehari. Pasien minum obat secara rutin. 18 hari setelah 
minum obat paket paru ini, pasien mengeluhkan adanya mual dan muntah, mata terlihat kuning dan nafsu makan yang berkurang. Pada pemeriksaan fisik ditemukan sklera ikterik dan hepar teraba 3 jari bawah arcus costarum, 3 jari bawah prosesus xiphoideus, pinggir tajam, permukaan rata, konsistensi kenyal, tidak nyeri tekan dan lien tidak teraba. Pada pemeriksaan laboratorium didapatkan peningkatan SGOT/SGPT $84 / 137 \mathrm{uL}$, bilirubin total $10,4 \mathrm{mg} / \mathrm{dl}$, bilirubin direk $8,3 \mathrm{mg} / \mathrm{dl}$, bilirubin indirek $2,1 \mathrm{mg} / \mathrm{dl}$, Gamma GT 459 u/l dan Alkali Phospatase 142 u/l.

Pada tahun 2011, American Association for the Study of Liver Disease (AASLD) menetapkan bahwa peningkatan kadar alanin aminotransferase (ALT) lebih dari tiga kali batas atas normal (BAN) dan peningkatan bilirubin total lebih dari dua kali BAN dapat digunakan sebagai kriteria untuk menentukan ada tidaknya kelainan signifikan pada parameter laboratorium hati. Peningkatan kadar enzim hati alanin aminotransferase (ALT), aspartat aminotransferase (AST) dan alkali fosfatase (ALP) dianggap sebagai indikator jejas hati, sedangkan peningkatan bilirubin total dan terkonjugasi merupakan parameter untuk menilai fungsi hati secara keseluruhan. Penilaian pola jejas hati sangat penting karena obat-obat tertentu cenderung menyebabkan jejas dengan pola khas pula. ${ }^{2,5,6}$

Penyebab drug-induced hepatitis pada pasien ini diduga karena obat anti tuberkulosis yang dikonsumsi pasien, dimana menurut literatur jejas hati hepatoselular (atau sitolitik) menyebabkan peningkatan kadar ALT dan AST serum yang bermakna, biasanya mendahului peningkatan bilirubin total, disertai sedikit peningkatan ALP. Contohnya adalah jejas hati imbas isoniazid. Hepatotoksisitas isoniazid ditingkatkan oleh alkohol, rifampisin dan pirazinamid. Studi-studi terakhir menyatakan bahwa hepatotoksisitas karena isoniazid serta terhadap terapi antituberkulosis kombinasi yang mencakup isoniazid lebih besar kemungkinannya terjadi pada pasien dengan hepatitis B kronik. Pada beberapa pasien dijumpai gambaran yang mirip dengan hepatitis kronik. Pasien yang sedang diterapi isoniazid sebaiknya dipantau fungsi hatinya secara cermat. Prognosis jangka pendek maupun jangka panjang jejas tipe hepatoselular mengikuti "Hukum Hy". Hukum ini dipopulerkan oleh Hyman Zimmerman, seorang hepatolog yang tertarik pada drug-induced hepatitis. Hukum Hy menyebutkan bahwa $10 \%$ pasien dengan drug-induced hepatitis mengalami ikterus dan dari jumlah tersebut, $10 \%$ akan meninggal karena druginduced hepatitis. ${ }^{7,8}$

Pasien dengan pembawa virus hepatitis, riwayat hepatitis akut serta konsumsi alkohol yang berlebihan apabila tidak terdapat bukti penyakit hati kronik dan fungsi hati normal dapat mengkonsumsi OAT standar. Reaksi hepatotoksik lebih sering terjadi sehingga perlu diantisipasi lebih lanjut. Pada pasien dengan penyakit hati lanjut dan tidak stabil, pemeriksaan fungsi hati harus dilakukan sebelum pengobatan dimulai. Semakin tidak stabil dan lanjut penyakit hatinya maka semakin sedikit obat hepatotoksik yang bisa digunakan. 5,6,7

Pada pasien ini OAT kategori 1 dihentikan dan diganti dengan obat etambutol $1 \times 750 \mathrm{mg}$ dan inj streptomisin $1 \times 750 \mathrm{mg}$ (iv), sambil memantau SGOT/SGPT per 3 hari, setelah SGOT/SGPT perbaikan, ditambahkan desensitisasi INH sampai dengan dosis penuh (300 mg). Selama itu perhatikan klinis dan periksa laboratorium saat pemberian INH dosis penuh, bila klinis dan laboratorium kembali normal, tambahkan rifampisin, desensitisasi sampai dengan dosis penuh (sesuai berat badan) sehingga paduan obat menjadi RHES. ${ }^{5}$

Sebelum memulai pengobatan TB, sebaiknya dipantau setiap 2 minggu selama awal dua bulan pada kelompok berisiko seperti pasien dengan gangguan hati yang sudah ada, alkoholik, lansia dan gizi kurang. Hal ini tidak hanya menjadi tanggung jawab para profesional kesehatan akan tetapi pendidikan kesehatan ini harus dibebankan kepada semua pasien yang menjalani pengobatan TB secara rinci tidak hanya mengenai kepatuhan dan manfaat dari OAT tetapi juga efek samping. Para pasien harus waspada dan melaporkan segera jika terjadi gejala yang mengarah pada hepatitis seperti hilangnya nafsu makan, mual, muntah, ikterik, yang terjadi selama pengobatan. Selanjutnya, kondisi klinis pasien harus dinilai tidak hanya dalam hal pengendalian penyakit tetapi juga dalam gejala dan tanda-tanda hepatitis pada pasien diikuti. ${ }^{8,9}$

\section{SIMPULAN}

Dilaporkan suatu kasus pada seorang lakilaki dewasa yang menderita TB milier-HIV dengan drug-induced hepatitis. Diagnosis ditegakkan berdasarkan gejala klinis, pemeriksaan fisik, radiologis dan USG. Respon yang baik dengan penghentian OAT kategori 1 dan terapi desensitisasi.

\section{DAFTAR PUSTAKA}

1. Robbins SL, Kumar V. Paru dan saluran nafas atas. Dalam: Anindita AY, penerjemah. Buku Ajar Pulmonologi Vol 2. Edisi 7. Jakarta: EGC; 2015.

2. Abdurrachman SA. Penyakit Hati Akibat Obat. Dalam buku ajar IImu Penyakit Hati. Editor: Sulaiman A, Akbar N, Lesmana LA. Jakarta: Sagung Seto; 2012: 265-74.

3. Mehta, Nilesh MD. Drug-induced Hepatotoxicity. New York: Departement of Gastroenterology and Hepatology; 2010.

4. Verma S, Kapliwitz N. Diagnosis management and prevention of drug-induced liver injury. Gut 2010; 58; 1555-1564.

5. Bjornsson ES, Bergmann OM, Kvaran RB, Olafsson S. Incidence, presentation, and outcomes in patients with drug-induced liver injury in the general population of Iceland. Gastroenterology. 2013; 144(7):1419. 
6. Pugh AJ, Barve AJ, Falkner K, Patel M, McClain CJ. Drug-induced liver injury. Clin Liver Dis. 2009; 13(2): 277-294.

7. USFDA Guidance for Industry. Drug-induced liver injury: Premarketing Clinical Evaluation. Silver Spring: US Food \& Drug Administration; 2009. Diunduh dari https://www.fda.gov/downloads/guidances/UCM1 74090.pdf.

8. Tajiri K, Shimizu Y. Practical Guidelines for Diagnosis and Early Management of Druginduced liver injury. World J Gastroenterol. 2008; 14(44): 6774-6785.

9. Russmann S, Kullak-Ublick GA, Grattagliano I. Current Concepts of Mechanism in Drug-induced Hepatotoxicity. Current Medicinal Chemistry. 2009; 16(23):3041-3053. 